\title{
Campus Environment and Cultivation of College Students' Core Values
}

\author{
Ying-Ying $\mathrm{JI}$ \\ School of Marxism, Tianjin University of Technology, Tianjin \\ Email:512318585@qq.com
}

Keywords: Campus environment, Core values, Socialist core values, Education.

\begin{abstract}
College time is a stage that college students' values tend to be mature and fixed with strong plasticity. Campus environment is an important platform for college students' education and spiritual civilization, and also a major place to develop socialist core values. Therefore, envisaging the necessity of cultivating college students' core values, knowing current conditions and existing problems of core values education in campus environment, and understanding measures of optimizing campus core values are significant for cultivating college students' socialist core values and have profound and permanent influences on socialist modernization.
\end{abstract}

\section{Introduction}

Marx believes that "The environment and human is an organic unity. Since a man's characters are caused by environment, the environment must be humane.” Harrold Perkin, an England educational historian, points out that college is a power station of human society, affecting a nation's rise and decline, and top-ranking colleges become an important symbol to measure a nation's comprehensive power. Thus it can be seen that campus environment is closely related to a man's character and even a nation's rise and decline. The campus environment is significant for contemporary college students to cultivate their core values. Realizing the necessity that college students practice socialist core values, envisaging the interaction between educational environment and values-cultivation, and exploring measures of cultivating college students' socialist core values not only guide contemporary college students' ideologies and behaviors, but also provide excellent future forces for socialist modernization.

\section{Necessity of Cultivating College Students' Core Values}

\section{The Influx of Harmful Western Ideologies and the Corresponding Shaking of Traditional Values}

As the reform constantly goes deeper, the competition among nations is not the counterbalance in economy and politic any more. The permeation and erosion of ideologies has a profound influence on the competition among nations. As a large number of Western ideologies and values stream into China, struggles from ideologies, outlook on life, world outlook and moral outlook lead to the result that socialist core values in college are influenced. As a result, some college students' ideal and faith is shaken, traditional values are distorted, patriotic consciousness is weakened and political consciousness is desalted. With slogans of "liberty and democracy" and through media platforms, some Western hostile forces attack Marxism, vilify socialist system and deny traditional Chinese culture. Correspondingly, some non-Marxism ideologies increasingly emerge, such as "historical nihilism" and "liberalism", shaking the traditional values and confusing people's ideologies. Values of contemporary college students determine the future value orientation and influence the construction of the overall values and core values of society. Therefore, contemporary college students should learn socialist core values through campus education, so as to prevent the negative influence of bad Western ideologies on college students.

\section{The Development of Economic Marketization and Diversified Value Orientations}

The market economy fosters economic growth, but its negative influences are gradually appearing. Some ideas like "money above anything else", "harming others to benefit oneself" and "putting 
profit first” emerge in people's minds. Although majority of college students develop good value orientations like helping others, self-discipline and pursuing lofty ideals in the process of economic development, minority of college students have bad value orientations like selfishness, pursuing a life of pleasure and lazy behaviors. These bad value orientations lack the incentive to pursue lofty ideals, and are easy to lead to negative phenomena that college students are depressed and cynical as well as they do not know Right from Wrong and even take illegal criminal activities. Facing a series of negative impacts brought by the environment changes in the new era, we should realize the importance of optimizing the environment of socialist core values education for college students. Only by establishing correct values can college students make contributions to their own life and the destiny of the country. Thus, the future country construction will have a more stable and long-term development.

\section{The Challenge of Network Culture and Imperfect Values Construction}

The popularity of the Internet makes the information transmission complicated and fast, but its inherent disadvantages impinge on college students' spiritual construction. Network violence, network pornography and virtual network block the construction of college students' values in current society full of material desires. Facing the impact of different ideas and ideologies, contemporary college students still have high plasticity under the condition that their values construction is not complete. The external environment affects their cultivation of outlook on life and values. During the formative stage of college students' values, the correct guidance at the plastic stage is the responsibility of school and society, and even the value pursuit of students themselves. Although current college students identify socialist core values, they have contradicted behaviors. The mismatch between cognition and behavior makes it difficult to practice socialist core values in current society. In this context, only by optimizing the environment of socialist core values education and strengthening socialist core values education can college students be guided to perfect their own values construction.

\section{The Current Situation of Core Values Education in Campus Environment}

\section{The Connotation of Campus Environment}

Campus environment refers to the sum total of environmental factors that influence students' learning and life in campus, which involves three elements--campus material environment, campus cultural environment and campus interpersonal environment. The campus environment is directly related to the cultivation of college students' socialist core values, which influences students' growth and success explicitly or implicitly.

\section{The Campus Material Environment is the Foundation of College Students' Values Education}

Social being determines social consciousness. In a similar way, the campus material construction determines the campus spiritual civilization. Places for activity, teaching and living, teaching facilities and environment greening belong to the campus material environment. These elements are the material guarantee for students' learning and living. A good campus environment with complete teaching-living facilities and clear teaching-living conditions can provide a powerful material guarantee for students' learning and living, which is a "hardware" condition for cultivating college students' socialist core values.

\section{The Campus Interpersonal Environment is the Guarantee of College Students' Values Education}

The campus interpersonal environment refers to the atmosphere of interpersonal relationship between teachers, between students and between teachers and students, among which the relationship between teachers and students is the most important. Although there are several channels for cultivating college students' socialist core values, teachers' teaching is the most direct and effective one. A good teacher-student relationship can ensure that students concentrate on 
learning and further improve the absorption rate of classroom. Once students open up to their teachers, teachers will have a concentrated influence on students' thoughts. As a kind of recessive environment atmosphere, the interpersonal environment is filled with students, influencing their psychology and thoughts. Establishing the harmonious interpersonal environment is a necessary guarantee for students to develop core values.

\section{The Campus Cultural Environment is the Core of College Students' Values Education}

The campus material environment is the foundation and the campus interpersonal environment is the support, while the campus cultural environment is the core of the campus environment. The campus cultural environment involves school spirit, study style, teaching style, cultural activities and related rules and regulations. The teaching style and culture is the soul of a school. The school "spirit" affects each student through the campus environment, which imprints in students' minds unconsciously and further influences the cultivation of students' values. This inherent educational orientation has characteristics of suggestibility, potentiality and permeability. Therefore, once values are developed, it is difficult to change them and they will have a long-term influence. In this sense, the cultivation of college students' socialist core values needs the important core--a good campus cultural environment.

\section{Current Problems of Campus Core Values Education Environment}

\section{The Poor Campus Climate for Learning and Learning Atmosphere}

The climate for learning and academic atmosphere are the foundation for cultivating high-quality talents, which are also the behavior style formed by students in the long-term campus and education environment, reflecting students' spiritual outlook. In the current campus environment, there are some general problems of learning climate and learning atmosphere. Phenomena that students are late for class, leave early, or even skip school become more and more serious. Students attach importance to professional courses and neglect public courses. Their learning purpose is that they do not fail in the exam. The reason for their slack attitude comes from the imperfect core values education. Core values, as a public course, are neglected by students mentally, so they do not pay attention to values education. The college life provides a relaxing and independent learning environment, but for most students, learning self-discipline is still a topic that cannot be stopped.

\section{The Low Controllability for Campus Network Environment}

For college students who are happy to accept new things, the Internet is an indispensable part in their life. However, as the philosophy says, everything has two sides. The Internet provides convenience for us, but it also feeds back some bad information to us. These seemingly convenient information channels always inundate with negative contents like virtual, extreme and pornographic contents. As a result, the construction of college students' core values is threatened. On the one hand, college students accept values education in college; and on the other hand, they sway their thoughts in the environment that people's thoughts are complicated on the Internet. In this ambivalence, some students deviate from correct values and further make irrational behaviors. The uncontrollable network environment blocks the construction of college students' core values to some degree.

\section{The Lack of Education System of Campus Values}

Although each college establishes its own institutional management system under the guidance of national policies, they do not inspect and supervise the core values education system harshly. Most colleges lack routine check. With the deepening of the reform in China, the education reform is also extremely urgent. However, the education reform will not be realized overnight and it will take a long time to achieve. We accept the ideological and moral education from primary school and still learn the course of ideology and politics in the university. It can be seen from students' growth process that the pure "teaching" cannot achieve the ideal teaching effect. The complete values education system should be constructed to make it institutionalized and standardized. The general 
values education system should be improved and the values education should be put in the important position.

\section{The Separation between College Education and Society}

School, society and family are an organic whole of student education. The successful values education cannot be separated without any one of these three elements. The educational goal, content and form of a school deviate from social life sometimes. For example, students who are to graduate do not know how to stratify their value goals. They usually set high goals so that they are frustrated in employment after graduation. They may find that what they learn from books is "not of much use" after they enter the society. Currently, majority of colleges' value education is too macro, and lacks the targeted and progressive education process. The ultimate goal of students' accepting education is to show their talents after entering the society. The "separation" between social and college education will have a deeper impact on students. Style choices are important for values education, so we should see values education from a macroscopic perspective and do it from details, regarding it as a progressive process rather than the result of some nodes.

\section{Measures of Optimizing Campus Values Education}

\section{Strengthen School Spirit, Teaching Style and Study Style Construction}

Good school spirit, teaching style and study style are the prerequisite for college students' healthy growth and socialist core values education in colleges and universities. The excellent study style construction of teachers needs to be cultivated. The construction of teacher teams needs to be strengthened so as to improve their moral level and professional ethics. To strengthen the construction of study style, teachers should take study as the main line of life, cultivating students' ability of independent learning and adjusting students' mind and body through extra-curricular activities. In addition, students should strengthen their own education reception ability and develop the habit of self-discipline and further treat professional and public courses equally. The good learning atmosphere should be created. Putting the healthy and active school spirit construction in the first place, a school should establish a unique school spirit that accords with its reality and strengthen the internal construction, so as to improve the quality of teachers and students in all aspects. A good school spirit reflects the spirit of a school, which can influence the construction of teaching style and study style. To strengthen the socialist core values construction, a good school spirit is the foundation and positive teaching and study style are external embodiments.

\section{Develop Campus Cultural Construction Vigorously}

The campus cultural construction is not only an important part of the socialism spiritual civilization construction and moral culture construction, but also an effective carrier to implement socialist core values education. To determine the mainstream campus culture spirit, the guiding ideology of Marxism is taken as the general policy, the common idea of socialism with Chinese characteristics is taken as the benchmark, as well as the national spirit with patriotism as the core and the time spirit with reform and innovation as the core are taken as the mainstream spirit of campus culture, so as to make Socialist Outlook for Honor and Dishonor become norms of students' outlook for life. Active and healthy campus culture activities should be undertaken, in which differences of college students' spiritual activities should be respected so as to raise students' value level in different cultural activities. The campus environment with cultural characteristics should be built, integrating culture deposits into each field of students' life. Cultural activities that students enjoy should be developed vigorously, in which socialist core values can influence each student in a relaxing environment unconsciously.

\section{Strengthen the Network Culture Construction and Build a New Education Platform}

The network environment has brought a serious challenge for college students' values. The cultivation of college students' socialist core values must grasp the unity of the campus and network as well as the integration between content and form, providing the powerful development condition 
for an active network culture. For instance, setting up courses about socialist core values education on platforms like school post bar and BBS, on which students can get the targeted course guidance through psychological tests; establishing the network psychological counseling room, through which students pour out their problems and teachers can guide them to get out of the wrong psychological region, and this measure respects students' privacy and relieves the embarrassment caused by face-to-face communication through the virtual network; and conducting network moral model awards regularly, in which each student is an elector and participator at the same time, and this incentive values cultivation mechanism is superior to the traditional punishment system. Students will abide by moral norms unconsciously and form positive values.

\section{Combine School Education with Family and Society}

Students get education not only from the school. The cultivation of socialist core values needs the combination of school education with family and society. Family has a profound and long-term influence on the cultivation of college students' core values. Children who are spoiled in a family have the value orientation of selfishness; while children who are treated strictly have the cold and even extreme values. Once these values are formed, school education cannot change them in a short time. Therefore, the premise of cultivating students' socialist core values is that parents should accept education and take appropriate education modes so as to exploit a "shortcut" for students' stepping into school and society. Meanwhile, when school is carrying out the socialist core values education, it should fully consider the integration with society and further develop social practice activities widely. Through contacting with society, students can know norms and codes of behavior of the society and exercise their tenacious quality so as to develop the spirit of bearing hardship and strengthen the adaptability to the society. The socialist core values formed in practice can facilitate students to accept and practice socialist core values.

\section{Conclusion}

As the basis and carrier of correct values, the campus environment is closely related to the cultivation of college students' socialist core values. Some measures, such as strengthening the construction of school spirit, teaching style and study style, developing the construction of campus culture and network culture, and combining the campus education with family and society, are taken to develop high-quality talents who have independent personality, can distinguish between right and wrong and can adapt to the society. Developing these high-quality talents is the aim of school education and also the requirement of national development. The joint efforts of the school and contemporary college students are needed to cultivate talents who meet the need of socialist construction. It is the responsibility and mission of each person to cultivate and practice socialist core values.

\section{References}

[1] Jianhua Xia. Inheritance and development--college students' socialist core values and ideological-political education innovation in the new era. Southwestern University of Finance and Economics Press. 2015.7.(In Chinese)

[2] Chengjun Zheng. Guidance and construction of ideals and beliefs--the contemporary college students’ socialist core values. Tsinghua University Press. 2010.11.(In Chinese)

[3] Xianjun Liu. On orientation of colleges and universities. Journal of Higher Education. 2003.(In Chinese)

[4] Li Liao. Reading of classic quotes of Marx and Engels. Liaoning People’s Publishing House. 2014. (In Chinese) 